\title{
Justification for IT Investments: Evaluation Methods, Frameworks, and Models
}

\author{
Article by Godfred Yaw Koi-Akrofi \\ Dean-School of Science and Technology, Dominion University College, Ghana \\ E-mail: godfred_akrofi@texilaconnect.com,g.koi-akrofi@duc.edu.gh, \\ godfred_akrofi@yahoo.com
}

\begin{abstract}
The productivity and profitability paradox in IT investments literature have made the work of IT managers very difficult in justifying for IT investments. Another difficult issue to grapple with by IT managers is how to measure or evaluate intangible benefits. These problems have led to the proposition of many IT evaluation frameworks/models and methods by researchers. This works aims to review a number of these frameworks/models and methods to see the way forward in this business of IT investments justification. About 40 categories/sets of research outputs or articles out of more than 50 articles reviewed were used for this work. The results showed that tangible benefits are not enough to justify for IT investments as they mostly point to corporate benefits which are short term, and that the justification of intangible benefits which are more strategic, must be included to make the justification process complete no matter how difficult it is. Again, no evaluation framework/model with its associated methods of evaluation is a panacea to the evaluation problem; evaluation depends on so many factors, and so is contextual. Also, the firm must factor into the evaluation process its corporate and strategic objectives. Lastly, in most cases, IT evaluation is seen as a must do, and therefore does not require that justification is done.
\end{abstract}

Keywords: Justify, Evaluate, Tangible, Intangible, Information Technology, Framework.

\section{Introduction}

LinA, Bou-Wen (2007) mentioned that Information technology (IT) has become an inevitable, important component of firm capability and also something that sustainable competitive advantage can be derived from. LinA continued to establish the fact that regardless of the above statement, empirical results of the relationship between IT capability and firm performance is still equivocal. This confusion is due to inconsistent or conflicting results from research, and this has contributed to the ambiguity for IT managers in justifying IT spending. Studies concerning the relationships between investment in IT and organizational performance and productivity (or value creation) have revealed positive and noteworthy effects of such investment in some cases (Barua, Kriebel, \& Mulhopadhyay, 1995; Brynjolfsson \& Hitt, 1996; Kaplan, Krishnanm, Padman, \& Peters, 1998; Lehr \& Lichtenberg 1998; Mahmood \& Mann, 1993; Rai, Patnayakuni, \& Patnayakuni, 1997), while in other cases, studies have revealed no noteworthy relationship (Berndt \& Morrison, 1995; Koski, 1999; Strassman, 1985; Strassman, 1990). Some reasons have been given to these contradictory results; some researchers attribute it to inadequate data and flawed methodology (Brynjolfsson, 1993; Sircar, Turnbow, \& Bordoloi, 2000). YiHua and Mykytyn (2002) also giving their view on the same subject mentioned that handling IT investment as a black box without looking further at what is going on inside the box could be an even bigger cause. 
This productivity and profitability paradox in IT investments literature have made the work of IT managers very difficult in justifying for IT investments. Another difficult issue to grapple with by IT managers is how to measure or evaluate intangible benefits. These problems have led to the proposition of many IT evaluation frameworks/models and methods by researchers. This works aims to review a number of these frameworks/models and methods to see the way forward in this business of IT investments justification.

The general objective of this work is to contribute to the general body of knowledge and research work in the area of IT investments/projects justification and benefits. The research work is also aimed at recommending or proposing a sure way forward in terms of IT investments justification. To achieve the general objective, the research explores from literature the various IT evaluation methods/frameworks/models.

\section{Materials and methods}

A detailed extant literature review is conducted relating to IT investments benefits and justification/evaluation frameworks/models/methods. This work only deals with secondary data, primarily from journal articles. About 40 categories/sets of research outputs or articles out of more than 50 articles reviewed are used for this work. No primary data is employed for this work. Articles were sourced from databases such as Google Scholar, Research Gate, Academia.edu, Google search engine, Emerald, Springer, and so on. The main themes used for the search are IT investments, Justification for IT investments, IT investments Evaluation Methods, IT investments benefits determination, value creation beyond IT investments, and so on. Some of the limitations encountered with this methodology are the difficulty in getting most current articles on the subject matter from databases, and also the fact that some databases cannot be accessed until payment is made. This is worrying as it can affect the results of the research.

\section{Results and discussions}

\section{Dimensions of IT investments evaluation}

From the articles reviewed, it is clear that justification for IT investments is one of the tough things to do in delivering IT projects. Gunasekaran, Love, Rahimi, and Miele (2001) explained the involvedness of the justification of IT investment from the view point of the numerous intangibles and non-financial benefits which are intrinsic in the execution or implementation of IT (Irani, 1999; Irani, Ezingeard, Grieve \& Race, 1999; Swamidass \& Kotha, 1998). They also established that the full benefits of IT investments are normally obscured when purely traditional or conventional methods are employed (Farbey, et. al, 1992). For the difference in strategic considerations (Irani, Ezingeard, \& Grieve, 1997; Peppard \& Ward, 1999; Hares \& Royle, 1994), and the fact that each investment is unique with its own benefits and cost different from all others, it is always maintained that no one method is deemed or considered best in this business of justification of IT investments. In view of this, trying to find a method to deal with all benefits is seen as too equivocal and impracticable.

Evaluation is exceptionally setting specific: Although the literature of IS evaluation prescribes the utilization of formal evaluation techniques, once in a while it is vital to rapidly pick up understanding of a new type of information system or product with a fairly casual evaluation process. Formal evaluation does not appear to be imperative or important for each situation (Hallikainen \& Chen, 2005). This suggests that environmental factors play a major role in the evaluation. Environmental factors determine the setting or context in which the organization is operating. Firms should consider their unique industry conditions before making the case for and adopting the latest technology. Improved understanding of these environmental conditions may help firms determine which parts of their business stand to benefit the most from investments in Information technology and act proactively (Dale \& Muhanna, 2009). Karlsson and Stypsanelli (2012) uncovered that several benefits are considered amid the decision making process of the investment, however these benefits are essential to the ultimate choice or decision and beat certain 
budgetary limitations, and that out of these benefits, customer relations and business effectiveness or efficiency are the ones that influence most the decision making process. They however maintained that environment dimension can likewise be added to the benefits assessment/appraisal level. To enhance the contextual argument with regards to IT ventures assessment, Wessels (2003) is of the view that in making vast or potentially complex choices or decisions, the way toward assessing IT is the application and ingestion of a scope of info data which incorporates information, assessment procedures, individual experience, individual learning/knowledge, corporate or departmental legislative issues, individual wishes and instinct. This goes to affirm that IT assessment/evaluation is multifaceted; it does not just include formal assessment strategies, for example, the accounting/financial assessment techniques. Gunasekaran, Love, Rahimi, and Miele (2001) consent to this when they said that current accounting assessment process, for investment justification in IT, for example, Return on Investment (ROI) is not sufficient to warrant an investment decision. Dekleva (2005) likewise repeated that not very many investigators or analysts bolster the idea that ROI or comparative measures are adequate and ought to dependably be utilized to legitimize or justify IT investments. Many people are of the view that since these measures do not include all secondary benefits from such investments, such measures are inadequate. Experience of key stakeholders in the IT projects environment is key, as they bring on board skills and knowledge that are not found in books and in literature. To some organizations, evaluation is not necessary as they see or consider IT investments as a 'must do' and something that is not negotiable. Dekleva (2005) opined that managers simply know that a specific system is required to just remain in business. In such cases, it is viewed as a mandatory operational expense requiring no support by any stretch of the imagination or no justification at all.

Easy to use, not detailed, unreliable tools and techniques being used by managers over time has resulted in major IT failures (Hochstrasser, 1992). Voss (1986) claims most Technology based projects do fail primarily because of economic justifications.

\section{Justifying tangible and intangible benefits}

One of the difficult areas that make managers shy away from IT evaluation is justifying intangible benefits. Tangible benefits are easily determinable by accounting measures, but intangible benefits are difficult to determine. This has led to a number of frameworks and models in literature worth discussing. There are numerous intangible benefits offered by IT, which are not of a quantifiable sort but rather basic to the perseverance of an organization (Gunasekaran, et. al, 2001). Intangibles can be observed from a process point of view when examining resources and activities, a legal viewpoint when talking about property rights, a standard setting stance when pondering about recognition criteria, and from a managerial angle when examining key or planned investments (Kristandl \& Bontis, 2007). Oliver, Barrick and Janicki (2009) in their work called attention to the fact that persuading management regarding values for intangible items is truly a troublesome thing which should be overcome. They kept on to reveal the difficulty that IT supervisors/managers experience to create measurement techniques for intangibles, despite the fact that they comprehend the requirement for the estimation/measurement of intangibles. To cure this, they suggested that on a start, a couple of intangibles can be measured by getting management endorsement. This ought to be followed with a survey or review taking into consideration actual intangible value versus the project plan, and once this is done, the process may start again with more intangibles considered on ensuing projects. Oliver, Barrick, and Janicki (2009) again came out with recommendations and best practices for the inclusion of intangible items in IT projects. Firstly, they said the value of intangible benefits in every related IT project must be considered. This means a conscious effort must be made regardless of the difficulty, to consider intangible benefits from the scratch. Secondly, that the business unit manager should be the project champion. This is important because a Business Unit Manager's primary responsibility is to ensure that a business unit - a particular segment of a company, is meeting goals that contribute to the overall success of a company. The position has a broad range responsibilities: From analyzing market trends and training and mentoring staff, to creating and 
implementing strategies to reach targets, Business Unit Managers do it all. No wonder the third point requires that business unit managers must establish the value of intangibles. Fourthly, stakeholders are expected to build on a history of successful previous projects. This should not only be in the minds of people, but must be documented to serve as models to be referred to in the delivery of current and future IT projects. The fifth point requires that intangibles be tied to corporate strategy. This will help managers appreciate better the intangible benefits, and can go a long way to help convince management easily of the need to embark on the project/s. Lastly, completed projects must be evaluated to ensure that intangible benefits were realized, show positive signs of realization or otherwise.

Gomez and Pather (2012) gave an alternate bend to the entire definition and comprehension of tangible and intangible benefits. They pitched their dialog on the encounters or experiences of ICT assessment/evaluation in the expansive business condition or environment, and prescribed that it is not adequate to concentrate on the effortlessly quantifiable tangible and quantifiable benefits of ICT. They motivate that the intangible benefits of ICT on development, for example, empowerment, confidence and social union or cohesion are more imperative from a formative point of view. As far as classifying benefits, they did a very good job. They said IT Benefits are either quantifiable (can be measured) or unquantifiable (cannot be measured or more difficult to measure), and both can be tangible or intangible. Quantifiable tangible may be objectively measured; e.g. increase in revenue; reduction in costs. Quantifiable Intangible is difficult to measure objectively, e.g. obtaining information faster; improved customer satisfaction. Unquantifiable tangible is one that precise impact on profitability cannot be measured, e.g. better information; improved security, and unquantifiable intangible, one that is difficult to put a financial value to the benefit, e.g. increased customer confidence; customers or employees' perception of the firm's product. They also came out with the differences between Business IT and ICT and Development with respect to phases of Impact Evaluation. The early phase is considered quantifiable with tangible outputs. For Business IT, it is at the Automate level where we measure technical aspects of IT (rate of information flow, accuracy, timeliness), and for ICT and Development, it is at the Euphoria level where we have quantifiable outputs (number of computers, number of users, rate of bandwidth consumption, teledensity, illiteracy rate, and so on.). The Intermediate phase is considered to be measurable with mostly tangible outcomes. For Business IT, it is at the Informate level where we have IT production and project implementation, and for ICT and Development, it is at the Instrumental level where we have economic outcomes (income generation, business opportunities, and so on. The Mature phase is considered unquantifiable with intangible impacts. For Business IT, it is at the Transformate level where we have service perspective and intangible benefits (trust, loyalty, brand, and so on.), and for ICT and Development, it is at the Intangibles level where we have aspirational outcomes (empowerment, self-esteem and self-worth, social cohesion and social fabric); citizen empowerment (relationship with governments); Individualized motivator factors (achievement, recognition).

Gunasekaran, Love, Rahimi and Miele (2001) maintained that most IT investment benefits evaluation are based on tangible benefits due to the primary aim of IT investment: to improve operational efficiency of an organization so as to reduce costs and improve profit levels. Regardless of this trend, Gunasekaran, et. al. (2001) pointed out that there is a growing desire and appreciation in managers now to consider the wider strategic implications of an IT infrastructure, and making investments to help revamp their business processes. Because of this, many qualitative benefits are being appreciated, and usually include improved customer support and greater product flexibility, of which most of them may be difficult to evaluate and quantify, and which usually forces entities to even probably having to accept short-term losses, in order to reap long-term benefits (Hochstrasser, 1992; Wilner, Kock, \& Klammer, 1992; Belleflamme, 2001; Kulatilaka, 1984; Lefley \& Sarkis, 1997; Meredith \& Suresh, 1986).

Irani et al. (1999), Farbey et al. (1993), Ward, Taylor, and Bond (1996), and Maskell (1991) therefore suggests that traditional quantitative techniques are unable to bring out the qualitative benefits of IT investments. The question then is how to differentiate between corporate investments whose benefits are largely measurable or quantifiable with strategic IT investments which delivers a wide range of 
intangibles. Simmonds (1983) therefore suggest a shift from the former to the later, stressing on progress being measured against contribution towards the corporate strategy, and not how well it meets the criteria laid down by accounting/financial rules and regulations.

Gunasekaran, et. al (2001) revealed that literature supports the fact that many companies are unaware of even the methods to evaluate IT investments, and those who do even use old methods like cost-benefit analysis and the like (Kennedy \& Mills, 1992; Kumar, 1990; Primrose \& Leonard, 1987; Willcocks \& Lester, 1991). Again, Willcocks and Lester (1991) established that the most reputable sectors such as the financial services and manufacturing industries, with the exception of IT, have not changed their evaluation criteria since they first introduced IT. With this background, Gunasekaran, et. al (2001) proceeded to come out with a conceptual framework to deal with the problem of the existing techniques which do not merge all the aspects (tangible, intangible, and other benefits) of IT investments justification together. They took into account five input considerations that make for a complete justification of investments in IT projects. The considerations are: strategic considerations, tactical considerations, operational considerations, intangibles, and tangibles.

Tiernan and Peppard (2004) are of the view that in a typical organization, even non-tangible benefits should be converted into tangible measures to the effect that each unit/department should be able to make its own justification in a measurable way to merit IT investment. Doherty Mark (2005) supports this view, and went ahead to mention some of the intangible benefits (improved customer service, reduced wait times, increased public safety, decreased operational errors and attention to public health issues) which should be quantified or measured, though are difficult to do so. Varghese (2003) on the other hand thinks that basing everything on ROI is an exercise in futility, as ROI numbers do not ensure that technology investments will be in line with business strategy. He additionally recommends that ROI figures ought to just be utilized as a way to guarantee that the planning is comprehensive and that the entirety or wholeness of effect has been considered. McMahon (2004) agrees with Varghese (2003), but focuses specially on IT support in the human resources (HR) function. He does not seem to agree with researchers who also say that working to show positive ROI or developing a business case may be a waste of time. He explained that preparing a business case or estimating ROI involves fundamental planning and business thinking, which should be part of a basic business discipline. Lucas (1999), also taking the middle stance explained that the fact that profits from IT investments are not evident, does not mean they are nonexistent. Lucas (1999) additionally posits that not all things are quantifiable by say, ROI, and to that effect, each type of benefit ought to be considered critically.

\section{IT investments evaluation methods and techniques}

A number of ways were proposed by Gibson, Arnott and Jagielska (2004) addressing how intangible benefits are evaluated in IT projects. Employing Value Analysis method, a 'value' is assigned to variables which would normally be classed as intangible and not included into traditional evaluation techniques. The benefits may be visualized through prototyping of proposed systems. The method allows for both monetary and utility measures of intangible benefits. Establishing these 'values' may be a drawn-out and costly process. There are repeatedly questions about subjective measurement methods that do not deliver exact financial measures (Keen, 1981).

For Total Cost Analysis, Tayyari and Kroll (1990) upheld that after the measures are known, conventional financial measures might be utilized to allocate or assign a monetary value to the benefits. This method relies on subjective, proxy measures, and there is no clear direction on how to undertake the identification of the surrogate indicators. Combination Net Present Value (NPV) and Discussion with personnel was also proposed by Anandarajan and Wen (1999). This method aims to overcome 'esoteric' evaluation methods by using traditional Net Present Value (NPV) models. It relies heavily on the opinion of discussion participants, and has the tendency of introducing bias into the categorization of intangibles.

Quantification Technique was also proposed by Hares and Royle (1994) who opined that the valuation of the intangibles is open to questioning, due to inevitability of judgment involved in applying the 
DOI: $10.21522 /$ TIJMG.2015.03.02.Art027

ISSN: $2520-310 \mathrm{X}$

technique. Return on Management (ROM) was also proposed by Strassman (1990); ROM as a comprehensive framework, delivered the postulation that the organization's information costs are the costs of managing the enterprise/business/firm. Distinguishing between operational and management costs can be difficult. A lack of use (Willcocks \& Lester, 1991) in industry suggest problems with the usability of the approach. Negotiation and Imputation as a method of IT evaluation relies heavily on subjective judgment. It gives a real dollar or monetary value to the asset, instead of a "solace" proclamation (Remenyi, et. al, 2000). For Information Economics as a method, Parker and Benson (1988) said that it is based largely on subjective scoring, and can be time consuming due to the number of steps involved. It includes both quantitative and qualitative measures. The Multi-objective, Multi-criteria (MOMC) method is best applied to multifaceted or difficult projects. It accommodates multiple stakeholders easily, and can incorporate intangible factors. This method does not include output for traditional ROI calculations (Kenny and Raiffa, 1976).

There are more than sixty methods of IT investment evaluations, and that they are varied and grouped into four main categories (Hamaker, 2009): They are Financial methods (i.e. Net Present Value, Internal Rate of Return, and Cost Benefit Ratio), Operation method/management science methods (i.e. Analytical Hierarchy Process (AHP), and Decision/Bayesian Analysis), Technique specifically designed for particular IT and/or organizations (i.e. Information Economics, Bedell's Method, and Benefit/Risk Analysis) and Other methods (i.e. Balanced Scorecard, Critical Success Factors, and Value Chain Analysis). Regardless the variability of the methods, they all point to common goal, which is evaluating the value of IT investment.

\section{IT investments evaluation frameworks}

IT evaluation measures are different from frameworks/models or processes that are employed for IT evaluation. A number of the measures have already been discussed in detail. Touching on some of the frameworks, we start with Clemons and Weber (1990) who proposed seven principles in evaluating IT investment. It consists of the downside risks and upside opportunities, and among some of the benefits are: divisibility and expandability, marketing in-house systems, timing value, and flexibility and option value. Technology management classifications that explain three major benefits of IT investment were proposed by Irani and Love (2001), and they are strategic, tactical, and operational benefits. From these three categories of benefits, 23 metrics of IT values are realized or gathered. Bannister (2001) proposed a value categorization of IT value for public (non-profit) organizations. The values are put into six categories, and they are foundational, policy formulation, democratic, service, internal, and external. 30 metrics explain each of the categories of benefits.

Gunasekaran, Love, Rahimi and Miele (2001) and Chou, Chou and Tzeng (2006) uses considerations and benefits criteria to evaluate IT investment. The requirements to be satisfied in order for the IT investment to be successful is termed Consideration criteria, and the evaluation of values or benefits of the IT investment, benefits criteria. Gunasekaran, Love, Rahimi and Miele (2001) proposed five consideration criteria and one benefit criteria, while Chou, Chou and Tzeng (2006) proposed four consideration criteria and one benefit criteria. Together, both research groups came out with a total of ten and nine metrics for benefits evaluations.

Keramati and Songhori et al (2009) proposes a framework of IT evaluation that is established on input and output criteria. This is similar to the works of Gunasekaran, Love, Rahimi and Miele (2001) and Chou, Chou and Tzeng (2006); input is similar to consideration criteria whereas the output is the benefits of IT investment, and they further categorized into strategic, information, and transactional benefits. A list of nine benefits metrics of IT investment were identified under output criteria.

A framework that evaluate IT investment using business value and risk criteria was presented by Stewart and Mohamed (2002). They were able to identify four business values, and they are Return on investment, strategic match, competitive advantage, and strategic architecture alignment. 15 business value metrics are enumerated in this framework. Nasher, Kalantarian, Akbari, Suzangar, Kajbaf, and 
Madani (2011) came out with the ranked importance decision making criteria, which is a combination of the consideration criteria together with the benefits criteria in a same category. Under the category of strategic and operational and tactical, a total of ten decision-making criteria were listed.

Ross and Beath (2002) came out with a concept of four IT investment types and called them Process improvement, Experiments, Renewal, and Transformation. Process improvements dwell on operational outcomes of existing business processes. They explained that companies need a stable stream of business and technology experiments to learn about the capabilities and limitations of new technologies. They posit that renewal investments trade old shared technologies to more up to date, more intense or more lucrative ones. On transformation, they clarified that, transformation purposefully changes a company's infrastructure in ways that not only enable, but usually demand process change.

Peacock and Tanniru (2005) additionally isolated IT investments into four sorts, yet in various classes along two measurements: Application of IT (recognizing general from centred) and Measurement Complexity (ordered as low or high). In justifying IT investments, they employed the accounting idea or concept Activity Based Costing (ABC). The fundamental thought here is to consider business performance before and after the IT investment by taking a gander at the effect of investments on business activities and performance.

Specialists/Practitioners Rau and Bye (2003) draws out an alternate view on IT valuation. They initially characterize four IT value scopes: Expense Containment, Process Improvement, Customer Advantage, and Talent Leverage. They additionally isolate each of them into its three noteworthy subcomponents: Capital and Operating Expense, People, and Innovation, the last two a clear augmentation of normal core interest.

Lee (2004) posits that whiles different organizations fail to receive guaranteed rewards from IT investment, others have been useful and that effective IT investment cases show that business process design issues ought to be tended to when IT investment choices/decisions are made. Lee fuses IT investment with business process design and suggests a four-stage IT assessment technique: Strategic investigation, Business process upgrade/redesign, IT configuration, Performance evaluation.

Lee also comes out with a simple Mathematical Model and a Simulation Approach to rationally estimate organizational benefits of business process-incorporated IT investments. Lee moreover recognizes two general classifications of performance evaluation: money related (financial) and nonmonetary (non-financial), where the non-financial comprises of two noteworthy measurements: operational and strategic. While the operational extensions are commonly quantifiable (e.g., process duration, imperfection rates, and end-client fulfilment), the strategic scopes are generally not (e.g., product development/improvement capacity).

\section{Conclusion}

From the literature reviewed, it came out clearly that Intangible benefits are difficult to identify from the beginning and once identified, difficult to measure/quantify, and for that matter difficult to justify/evaluate. Tangible benefits are not enough to justify for IT investments as they mostly point to corporate benefits which are short term, and that intangible benefits justification must be included to make the justification process complete no matter how difficult it is. Again, intangible benefits are usually strategic in nature, requiring some time for realization, and must be seen as such; there should be no rush. It was also realised that no evaluation framework/model with its associated methods of evaluation is a panacea to the evaluation problem; evaluation depends on so many factors, and so is contextual. It depends on environmental factors such as the size of the firm, the type of IT investment, the industry the firm is operating in, the expertise of the stakeholders involved, the experience of key stakeholders involved, and so on. The process of evaluating IT is also the application and absorption of a range of input information which includes data, evaluation techniques, personal experience, personal knowledge, corporate or departmental politics, personal desires and intuition. This means that each firm should be able to access all these factors and factor them in their evaluation process. This will make each firm has a 
DOI: $10.21522 /$ TIJMG.2015.03.02.Art027

ISSN: $2520-310 \mathrm{X}$

unique process/framework/model that suits its best. Sometimes the firm should allow certain benefits, even though not a direct benefit, during the decision-making process to overcome the financial considerations (direct benefit). An example of such is customer satisfaction. This may not be easily measured, but can benefit the firm in the long term, and may translate into financial benefits in the end. To effectively do IT investment evaluation, the firm must also factor into the process its corporate and strategic objectives. To be informed about what the firm wants to achieve corporately and strategically will go a long way to inform stakeholders about the kind of tangible and intangible benefits that are expected; this will aid the evaluation process. IT investments is sometimes, and in fact, almost all the time seen as a must do, which requires that no justification is done. Every business is digitizing and going online. This requires huge investment in IT. Failure to tow this line will present your business as not serious and not ready for the competitive market. Customers will automatically drift to technology and innovation. This means that even though you may not be able to justify for the investment, you are bound to do if you want to stay in business and still have customers to serve.

In summary, the way forward for IT investments justification is that justification is unique to every firm, it is contextual, and so stakeholders must take into consideration environmental factors, corporate and strategic goals, experience and expertise of stakeholders, and so on, to design its own framework and measures to justify IT investments.

\section{References}

[1].Anandarajan, A., \& Wen, H. J. (1999). Evaluation of Information Technology Investment. Management Decision 37(4), 329-337.

[2].Bannister, F. (2001). Citizen Centricity: A model of IS value in public administration. The Electronic Journal of Information System Evaluation, vol. 1, no. 2.

[3].Barua, A., C. H. Kriebel, \& T. Mukhopadhyay. (1995). Information technologies and business value: An analytic and empirical investigation. Information Systems Research. 6, 1, 3-23.

[4].Belleflamme, P. (2001). Oligopolistic competition, IT use for product differentiation and the productivity paradox. International Journal of Industrial Organization, 19(1-2), 227-248.

[5].Berndt E.R., \& Morrison, C. J. (1995). High-tech Capital formation and Economic Performance in U.S. Manufacturing Industries; An Exploratory Analysis. Journal of Econometrics, 65(1), pp.9-43.

[6].Brynjolfsson, E. (1993). The Productivity Paradox of Information Technology. Communications of the ACM, 36(12), pp.67-77.

[7].Brynjolfsson, E., \& Hitt, L. (1996). Paradox lost? Firm-level Evidence on the Return to Information Systems. Management Science, 42(4), pp.541-558.

[8].Chou, T. Y., Chou, S. T., \&. Tzeng, G.-H. (2006). Evaluating IT/IS investments: A fuzzy multi-criteria decision model approach. European Journal of Operational Research, vol. 173 no. 3, pp. 1026-1046.

[9].Clemons, E. K., \& Weber, B. W. (1990). Strategic information technology investments: Guidelines for decision making. Journal of Management Information Systems, vol. 7, no. 2, pp. 9-28.

[10]. Dale Stoel, M. D., Muhanna, W. A. (2009). IT Capabilities and Firm Performance: A Contingency Analysis of the Role of Industry and IT Capability type. Information \& Management, Science Direct, Elsevier, Volume 46, Issue 3, Pages 181-189

[11]. Dekleva, S. (2005). Justifying investments in IT. Journal of Information Technology Management Volume 16, Number 3, ISSN \#1042-1319.

[12]. Doherty, M. (2005). Mapping ROI. American City \& County. Vol. 120, No. 2, pp. $32-34$.

[13]. Farbey, B., Land, F., \& Targett, D. (1992). Evaluating investments in IT. Journal of Information Technology, 7(2), 109-122.

[14]. Farbey, B., Land, F., \& Targett, D. (1993). IT investment: A study of methods and practices. UK: Published in association with Management Today and Butterworth-Heinemann Ltd. 
[15]. Gibson, M., Arnott, D., \& Jagielska, L. (2004). Evaluating the Intangible Benefits of Business Intelligence: Review and Research Agenda. Decision Support in an Uncertain and Complex World: The IFIP TC8/WG8.3 International Conference, Prato, Italy, 1 to 3 July, pg.295-305.

[16]. Gomez, R., \& Pather, S. (2012). ICT EVALUATION: ARE WE ASKING THE RIGHT QUESTIONS? Electronic Journal on Information Systems in Developing Countries (EJISDC), 50, 5, 1-14.

[17]. Gunasekaran, A, Love, P. E. D., Rahimi, F., \& Miele, R. (2001). A model for investment justification in information technology projects. International Journal of Information Management, vol. 21 no. 5, pp. 349-364.

[18]. Hallikainen, P., \& Chen, L. (2005). A Holistic Framework on Information Systems Evaluation with a Case Analysis. The Electronic Journal Information Systems Evaluation. Volume 9, Issue 2, pp. 57 - 64. Available online at www.ejise.com

[19]. Hamaker, J. L. (2009). Information Technology Investment Methodologies: An Investigation into Method / Technology Fit. Ph.D. dissertation, The Graduate College, University of Nebraska, Lincoln, NE.

[20]. Hares, J., \& Royle, D. (1994). Measuring the Value of Information Technology. Chichester, UK: Wiley.

[21]. Hochstrasser, B. (1992). Justifying IT Investments. Conference proceedings of the advanced information systems; The new technologies in today's business environment. London, UK (pp. 17-28).

[22]. Irani, Z. (1999). IT/IS investment decision making. Logistics and Information Management, 12(1), 8-11.

[23]. Irani, Z., \& Love, P. E. D. (2001). The Propagation of Technology Management Taxonomies for Evaluating Investments in Information Systems. Journal of Management Information Systems, vol. 17, no. 3, pp. 161-177.

[24]. Irani, Z., Ezingeard, J.-N., \& Grieve, R. J. (1997). Integrating the costs of an IT/IS infrastructure into the investment decision making process. The International Journal of Technological Innovation and Entrepreneurship (Technovation), 17(11/12), 637-647.

[25]. Irani, Z., Ezingeard, J.-N., Grieve, R. J., \& Race, P. (1999). Investment justification of information technology in manufacturing. The International Journal of Computer Applications in Technology, 12(2), 10-21.

[26]. Kaplan, D., Krishnanm, R., Padman, R., \& Peters, J. (1998). Assessing Data Quality in Accounting Information Systems. Communications of the ACM, 41(2).

[27]. Karlsson, E., \& Stypsanelli, M. (2012). IT investment decision making - the value of intangible benefits. Department of Informatics, Lund University.

[28]. Keen, P. G. W. (1981). Value Analysis - Justifying Decision Support Systems. MIS Quarterly 5(1), 1-14.

[29]. Kennedy, A. J., \& Mills, R. (1992). Post-completion auditing: A source of strategic direction? Management Accounting, 70(5), 26-28.

[30]. Kenny, R., \& Raiffa, H. (1976). Decision with Multiple Objectives: Preferences and Values Tradeoffs. New York, Wiley.

[31]. Keramati, A., Songhori, M. J., et al. (2009). An integrated Delphi/VAHP/DEA framework for evaluation of information technology/information system (IT/IS) investments. The International Journal of Advanced Manufacturing Technology, vol. 45, pp. 1233-1251.

[32]. Koski, H. (1999). The implications of network use production network externalities and public networking programs for firm's productivity. Research Policy, 28(4), PP. 423-439.

[33]. Kristandl, G., \& Bontis, N. (2007). Constructing a definition for intangibles using the resource based view of the firm. Emerald Group Publishing Limited, Management Decision, Vol. 45 No. 9, 2007 pp. 1510-1524

[34]. Kulatilaka, N. (1984). Financial, economic and strategic issues concerning the decision to invest in advanced automation. International Journal of Production Research, 22(6), 949-968.

[35]. Kumar, K. (1990). Post implementation evaluation of computer-based information systems. Communications of the ACM, 33(2), 203-212.

[36]. Lee, I. (2004). Evaluating business process-integrated information technology investments. Business Process Management Journal. Vol. 10, No. 2, pp. 214-233.

[37]. Lefley, F., \& Sarkis, J. (1997). Short-termism and the appraisal of AMT capital projects in the US and UK. International Journal of Production Research, 35(2), 341.

[38]. Lehr, W., \& Lichtenberg, F. (1998). Computer Use and Productivity Growth in U.S. Federal Government Agencies, 1987-92. Journal of Industrial Economics, 46(2), pp.257-279. 
DOI: $10.21522 /$ TIJMG.2015.03.02.Art027

ISSN: $2520-310 \mathrm{X}$

[39]. Linã, B-W. (2007). Information technology capability and value creation: Evidence from the US banking industry. Technology in Society, Science Direct, Elsevier, 29, 93-106.

[40]. Lucas, H.C. Jr. (1999). Information Technology and the Productivity Paradox: Assessing the Value of Investing in IT. New York: Oxford University Press

[41]. Mahmood, M.A., \& Mann, G. J. (1993). Measuring the Organizational Impact of information technology investment: an Exploratory Study. Journal of Management Information Systems, 10(1), pp.97-122.

[42]. Maskell, B. (1991). Performance measurement for world class manufacturing: A model for American companies. USA: Productivity Press.

[43]. McMahon, E. (2004). What Technology ROI Looks Like and Where to Find It? Canadian HR Reporter, Vol. 17, No. 2, pp.7, 9.

[44]. Meredith, J. R., \& Suresh, N. C. (1986). Justification techniques for advanced technologies. International Journal of Production Research, 4(5), 1043-1057.

[45]. Nasher, S., Kalantarian, M., Akbari, A., Suzangar, A., Kajbaf, M., \& Madani, N. (2011) Evaluation of IT Investment Methods and Proposing a Decision Making Model. In Proc. The European Conference on Information Management \& Evaluation, pp. 324-332, Reading, UK: Academic Publishing International Limited.

[46]. Oliver, A., Barrick, J., \& Janicki, T. N. (2009). Difficulties in Quantifying IT Projects with Intangible Benefits: A Survey of Local IT Professionals. Proc CONISAR, v2 (Washington DC), EDSIG, PP. 1-12

[47]. Parker, M., \& Benson, R. (1988). Information Economics: Linking Business Performance to Information Technology. London, Prentice-Hall.

[48]. Peacock, E., \& Tanniru, M. (2005). Activity-based justification of IT investments. Information \& Management. Vol. 42, No. 3, pp. 415 - 424.

[49]. Peppard, J., \& Ward, J. (1999). Mind the gap: Diagnosing the relationship between the IT organization and the rest of the business. Journal of Strategic Information Systems, 8, 29-60.

[50]. Primrose, P. L., \& Leonard, R. (1987). Performing investment appraisals for advanced manufacturing technology. Cost Management, 2, 34-42.

[51]. Rai, A., Patnayakuni, R., \& Patnayakuni, N. (1997). Technology investment and Business Performance. Communications of the ACM, 40(7), pp.89-97.

[52]. Rau, S.E., \& Bye, B.S. (2003). Are You Getting Value From Your IT? Journal of Business Strategy. Vol. 24, No. 3, pp. 16-20.

[53]. Remenyi, D., Money, A.H., Sherwood-Smith, M., \& Irani, Z. (2000). The Effective Measurement and Management of IT Costs and Benefits. 2nd Ed. Oxford: Elsevier Butterworth-Heinemann.

[54]. Ross, J.W., \& Breath, C.M. (2002). Beyond the Business Case: New Approaches to IT Investment. MIT Sloan Management Review. pp. $51-59$.

[55]. Simmonds, K. (1983). Strategic management accounting. In D. Fanning (Ed.), Handbook of management accounting. UK: Gower Publishing Company.

[56]. Sircar, S., J., Turnbow, L., \& Bordoloi, B. (2000). A Framework for Assessing the Relationship between Information Technology Investments and Form Performance. Journal of Management Information systems, 16(4), pp.69-97.

[57]. Stewart, R. \& Mohamed, S. (2002). IT/IS projects selection using multi-criteria utility theory. Logistics Information Management, vol. 15 no. 4, pp. 254-270.

[58]. Strassman, P. A. (1985). Information Payoff: The Transformation of Work in the Electronic Age. New York: Free Press.

[59]. Strassman, P. A. (1990). The Business Value of Computers. New Cannan, CT: Information Economics Press.

[60]. Strassmann, P.A. (1985). Information Payoff: The Transformation of Work in the Electronic Age, Free Press, New York.

[61]. Swamidass, P., \& Kotha, S. (1998). Explaining manufacturing technology use, firm size and performance using a multidimensional view of technology. Journal of Operations Management, 17, 23-37.

[62]. Tayyari, F., \& Kroll, D. E. (1990). Total Cost Analysis of Modern Automated Systems. Justification Methods for Computer Integrated Manufacturing Systems. New York, New York, Elsevier Science Publishers, 234241. 
[63]. Tiernan, C., \& Peppard, J. (2004). Information Technology: Of Value or a Vulture? European Management Journal. Vol. 22, No. 6, pp. 609623.

[64]. Varghese, J. (2003). ROI is not a Formula, it is a Responsibility. Journal of Business Strategy. Vol. 24, No. 3, pp. 21-23.

[65]. Voss, C. A. (1986). Managing advanced manufacturing technology. International Journal of Operations and Production Management, 6(5), 4-7.

[66]. Ward, J., Taylor, P., \& Bond, P. (1996). Evaluation and realization of IS/IT benefits: an empirical study of current practices. European Journal of Information Systems 5(4):218- 232.

[67]. Wessels, P. (2003). Justifying the investment in information systems. South African Journal of Information Management. Vol. 5(2).

[68]. Willcocks, L., \& Lester, S. (1991). Information systems investments: Evaluation at the feasibility stage of projects. The International Journal of Technological Innovation and Entrepreneurship (Technovation), 11(5), 283301.

[69]. Wilner, N., Kock, B., \& Klammer, T. (1992). Justification of high capital investment- an empirical study. The Engineering Economist, 37(4), 341-353.

[70]. YiHua, P. S., \& Mykytyn, P. P. (2002). Information technology investment and firm performance: a perspective of data quality. Proceedings of the Seventh International Conference on Information Quality (ICIQ-02). 